\title{
Factors Influencing Food Consumption among University Students
}

\author{
YATY SULAIMAN ${ }^{1 *}$, ZHARIANI SEHU MOHAMAD ${ }^{2}$, MOHD YUSRI SHAHRIL ISMAIL ${ }^{3}$ \\ ${ }^{1,2}$ School of Business Management, College of Business Management, \\ Universiti Utara Malaysia, Kedah, \\ MALAYSIA
}

${ }^{3}$ Southern Pipe Industry (Malaysia) Sdn Bhd

4577 Jalan Chain Ferry, Butterworth, Penang

MALAYSIA

\begin{abstract}
Vegetables and fruits are an important food component of a healthy lifestyle as it contains variety of nutrients. Ministry of Agriculture and Agro-based Industry Malaysia has showed in the AgroFood Statistics Book 2014 that the commodity consumption of vegetables and fruits kilograms per year from 2008 to 2014 has consistently increase and expected to increase. Studies on factors influencing the consumption of vegetables and fruits are still lacking in Malaysia. There appears to be relatively scarce research and analysis concerning Malaysia. Research aims to identify the attitude of having fruits and vegetables among students of University Utara Malaysia (UUM) by adopting product, price, promotion, place and knowledge as variables. Data were collected using the questionnaire method studied using the Statistical Package for Social Science (SPSS) version 22.0 application. Research was done to examine whether marketing mix factors, product, price, distribution, and knowledge affect the attitude of fruit and vegetable consumption among Universiti Utara Malaysia students. Findings indicates all the variables are significant except for knowledge on vegetables and fruits consumption. Hence, the accuracy of food intake in terms of the amount and the types of food consumed should be aware by the students.
\end{abstract}

Key-words: Food consumption, product, price, promotion, place and knowledge

Received: September 8, 2020. Revised: February 18, 2021. Accepted: February 27, 2021.

Published: March 6, 2021.

\section{Introduction}

Huge number of studies over the past few decades showed that there are some nutrients and other components found in fruits and vegetables. The key to good health and free of disease require exercise and healthy eating habits which contains fruits and vegetables. They are specially known to be important for health as it's naturally low in calories and provide more nutrients and dietary fibre [1]. Fruits and vegetables has great amount of vitamins, minerals, proteins, fibre and profunctional components which are low in fat, sodium and calories than any other foods [2]. They are important component for a healthy human diet.

To date, Malaysian food consumption are influenced by the growth of fast food restaurants offering high calories of foods with less fruits and vegetables. It has been mentioned that a healthy lifestyle is crucial to face the day a head [3]. To live a healthy and prosperous life, physical, mental, social well-being and freedom from disease are important [4]. Healthy eating help to prevent foodborne illness. It is recommended to have half a plate with fruits, vegetables, nuts and cereals [5]. Other than that, website "Produce for Better Health Foundation" (2011), shows that fruits and vegetables intake can protect human health and has been studied around the world. Based on National Agro Food Policy website 2011-2020, consumers nowadays are aware of healthcare and this has created increased vegetable production with expansion of minimal processed vegetable-based products such as vegetable juice, fast foods, frozen vegetables, and high-fibre vegetables. Request for vegetables is expected to rise from 1.6 million tonnes in 2010 to 2.4 million tonnes by 2020 , with an increase of $4.5 \%$ per annum. With 
this, the challenges Malaysia are facing till today is to deal with low-cost vegetable producers from Thailand and China. Those are the inability to meet domestic demand production with high production costs and competition.

Quit a numbers of researchers notified that consumer's behaviour studies involves demographics, beliefs and attitudes [6]. There are various factors related to consumption of fruits and vegetables such as demographics, attitudes, taste selection, knowledge and more. However, more previous studies have only focused apart from Malaysia, for example studies on the effectiveness of fruit intake among civil servants in Oyo province, [7] and studies on the knowledge regarding fruits and vegetable consumption amongst adults in urban areas in northern Nigeria [8]. Without any doubt, there are studies that refer to Malaysia but it is less compared to the one outside Malaysia. This has also been supported that, research on factors influencing consumption of fruits and vegetables in Malaysia are less [9]. Research on the factors of marketing mix and knowledge of food intake attitudes is still in-between few and less. This are among worrying issues regarding fruits and vegetables consumption among Malaysians university students. This problem may affect their health condition and the causes to certain disease. Therefore, measuring the factors influencing food consumption among university students are crucial.

Conventionally, consumer lifestyle is how a person lives and spends their time and money [10]. Malaysians mostly prefers to consume fast food rather than fruits and vegetables. Besides, technology advancement in the creation of various fast food products known as burgers, pizza, magi and many more has increased. According to 2016 Utusan, the government has allocated more than RM20 billion for health care. Although the budget allocated by the Malaysian government is large, Deputy Minister of Health Malaysia; Datuk Dr Hilmi Yahaya said that Malaysians health condition is at an alarming state. This is because $10 \%$ of Malaysians equals to 29.9 million were hospitalized in 2013 due to health problems. Willian Chan in the same article said that Malaysians nowadays are less; even do not like to eat dishes with plenty amount of nutrients such as fruits and vegetables.

\section{Literature Review}

\subsection{Attitude of Consumption of Fruits and Vegetables}

Attitude said to be a person's belief reflecting an action with or without positive effect [11]. There are few studies on fruits and vegetable consumption in Malaysia by other researchers but with very few among students, especially in Universities [12]. Barriers exist with fruit and vegetable consumption between lower salary groups in North Carolina is because of price [13]. A person's personal factors (e.g. knowledge, attitudes, and skills, social and behavioural influences) and environmentally friendly factors (e.g. access, cost, quality and supply) are having much influence towards fruit and vegetable consumption attitude [14]. An individual's knowledge and skills may influence the attitude of eating nutritious food in their life [15]. Fruits and vegetable consumptions among undergraduate students at Peradeniya University is only $267 \mathrm{~g}$ compared to $400 \mathrm{~g} /$ day as recommended by the World Health Organization (WHO) [12]. An individual choice of food is influenced by their belief, especially those involving health and collection of pesticides [16]. Among other factors influencing the attitude of fruit and vegetable consumption is the duration of time and working day [17].

\subsection{Marketing Mix}

Fruit and vegetable farming system has become an important factor domestic and international economic systems in today's modern marketing economics [18]. Fruit and vegetable farming affects the consumption pattern. With such a relationship, it is not possible to sell a product successfully without specialized talents and information of market policy and marketing mix involving the basic factors of successful sales and profitability [9]. There will be no economic market without marketing hence marketing goals will not be achieved without a marketing mix [19]. Fruits and vegetables marketing process consists of product planning, price formation, promotion and sales of products to customers to satisfy their needs, desires and demands [14]. These activities consists of meeting customers evolving needs, desires and figure out their willingness to buy fruit and vegetable [20]. Characteristics of fruits and vegetables influence the combination of 
elements in marketing mix. Since it's the final use product, the quality of a particular element with market mix should be taken into account, so that the organization will be able to pay attention for their activities and promotions.

\subsection{Products}

Consumer buying behaviour is their final decision whether or not to buy the product or services [21]. Product will attract buyer to buy the product or service offered to them [22]. Product is something real or unreal, offered by an organization to meet customers' needs [23]. This website also says that Marketers need to be cautious on the life cycle of a products so that they can focus on other challenges that may occur as the product changes at every point. Fruits and vegetables as products are vital in marketing mix. People who buying fruits and vegetables will be more interested in production programs, product quality, packaging materials, packaging, product labelling, and pricing. There is strong competition and growing demand and consumer quality has become an important factor to stay in the market, profitability, and agricultural and fruit development. The strategic concept of the business is based on product quality management, which makes it an advantage and a necessity of market competition.

H1: There is a positive relationship between products and the consumption of fruits and vegetables among UUM students.

\subsection{Price}

The second element of marketing mix is price. Prices brings revenue, while other elements of marketing mix represent cost. Basically, a product's price must be in line with basic features and characteristics of the product. Therefore, it must be equalling to the quality of the product, design, packaging, etc. Price policy of fruits and vegetables on farms observed in Malaysia set prices to the needs, wants and purchasing power of customers. At the same time, price provides optimal profitability. With price policy, fruit and vegetable producers will be able to influence the demand and quantitative increase in consumption structure. Prices and demand are usually inversely proportional. Price is the evaluation to how much consumer able to pay to get a product or services. Price may influence consumers' purchase intentions of organic products. Premium price is an extra amount paid for a particular product compared to the normal price and this can indicate the willingness of consumers to pay for organic products [24].

Solely, prices are not only influenced by demand, but also by rapid changes in customer tastes, availability of other products that can serve as a substitute for fruits and vegetables as well as consumer income. All variables of the marketing mix are closely related, which means that price-related decisions are related to product, place and promotion.

$\mathrm{H} 2$ : There is a positive relationship between prices and the consumption of fruits and vegetables among UUM students.

\subsection{Place}

Another important marketing channel is place to distribute products to each customer. Place states how the product is distributed and reaches the consumer. Past studies have shown that one of most challenging part of product marketing is place channels [25]. Writing by [26] justified that businesses must know the successors of place resources to distribute products and services even if isolated to the largest group in [27]. Place covers the environmental impact associated with good packaging, transportation and distribution to its users [28]. Currently, limited awareness and the absence of fruits and vegetables and services inhibit green consumption [29][30].To achieve rapid development of fruit and vegetable production, consumers in Malaysia need to track potential consumers for their products and select appropriate distribution channels in Malaysian market and international markets.

H3: There is a positive relationship between place and the consumption of fruits and vegetables among UUM students.

\subsection{Promotion}

The pattern of food consumption and eating pattern may influence food and information of it [31]. Today's consumers are requesting additional and precise information related to nutritional fact, ingredients, and food safety on their daily food consumption. Marketers and social media have connected communities everywhere the world through communication 
channels in shaping consumer response. With its exposure on variety of out information and purchasing attitudes [31]. Manufacturers reach out and encourage customers to buy their products with all possible media. The most famous media where promotional messages are sent to end-users are newspapers, TV, radio, mail, and new media such as satellite cable TV, and others. Advertisements needs to match the goals and objectives. There is a need for manufacturers to research on nutrition food advertising so that they can identify what can be expected from a particular product and what requirements will be satisfactory for each product produced by fruit and vegetable manufacturers.

H4: There is a positive relationship between promotion with the attitude of consuming fruits and vegetables among UUM students.

\subsection{Knowledge}

Knowledge of food is one of the important factors consumers consider before making a decision on food-related functions [32] [33]. The reason is where current information of functional foods and to get information may help to choose the right kind of functional food [31]. Knowledge of health nutrition encourage changes in eating habits [32]. But, it is not completely understand by the consumers to decide food selection, especially in functional food selection. A cross-sectional keratin study in nine European countries was done to find the determinants fruits and vegetables intake among children [33]. Researchers' notices daily fruit and vegetable intake had a significant relationship with the proposed knowledge for fruit and vegetable consumption. Apart from this, researches also that knowledge of recommendations for fruit and vegetable intake significantly predicts fruit intake at studies done in nine of the countries $(100 \%)$ and vegetable intake in six countries studied (67\%).

H5: There is a positive relationship between knowledge and the attitude of fruit and vegetable consumption among UUM students.

\section{Methodology}

\subsection{Research Framework}

Research framework of this study was adopted from past research. Framework illustrates factors influencing attitude of fruits and vegetable consumption among UUM students. Independent variables consist of marketing mix (product, price, place, and promotion), and knowledge. While dependent variable is attitude of consuming fruits and vegetables. All independent variables will be tested and analysed if they have a significant relationship without including demographic factors. Framework of the study is based on the literature review of [34] as in Figure 1 below.

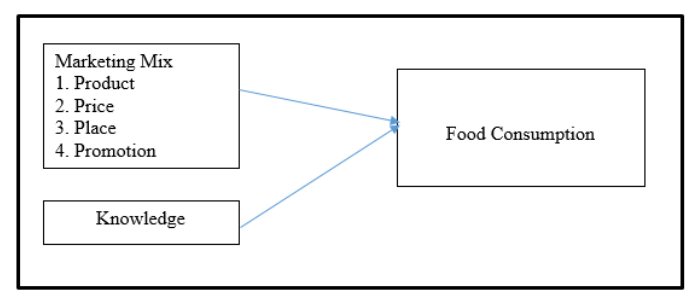

Figure 1: Research Framework

Based on the adapted research framework, there are five hypotheses that have been formulated and labelled as $\mathrm{H} 1, \mathrm{H} 2, \mathrm{H} 3, \mathrm{H} 4$, and $\mathrm{H} 5$. The five hypotheses are as follows:

H1: There is a positive relationship between products and the consumption of fruits and vegetables among UUM students.

$\mathrm{H} 2$ : There is a positive relationship between prices and the consumption of fruits and vegetables among UUM students.

H3: There is a positive relationship between place and the consumption of fruits and vegetables among UUM students.

H4: There is a positive relationship between promotion with the attitude of consuming fruits and vegetables among UUM students.

H5: There is a positive relationship between knowledge and the attitude of fruit and vegetable consumption among UUM students. 


\subsection{Research Design}

Quantitative approach was used in this study where it emphasizes objective and statistical measurement or analysis of number of data collected through questionnaires. Pilot study was used to test the instruments. Pilot study was carried out by collecting data only once to examine reliability and validity of constructed instrument. Data were collected from University Utara Malaysia respondents.

\subsection{Population and Sample Size}

According to corporate planning unit (2015), there we approximately 17, 398 undergraduate students from field of study and countries at University Utara Malaysia. This study only focuses on the limited population as it examines only local full time students who are approximately 16, 715 students. Sample size of 375 to 377 based on the specified population has proposed by [35]. 450 questionnaires were distributed. Excess questionnaires are intended to cover in the event of any damage or incomplete return to the returned questionnaires.

\subsection{Data Collection}

Sample random data collection method was used for data collection. Respondents were randomly selected among UUM students to answer the questionnaire. Data collected using the questionnaire method is a reliable data collection method when it involves a large number of respondents [36]

\subsection{Research Instruments}

Research questionnaire consists of four sections. The first part has five questions on demographic details of respondents related to gender, age range, marriage status and frequency of buying fruits and vegetables. The second part is related to consumer attitudes with 26 questions.

Part three of the questionnaire related to the marketing mix which then divided into four parts namely product (8 questions), price (6 question), place (6 questions) and promotion (10 questions). Followed by the last part; part four related to user knowledge containing 10 questions. All four sections except sections one and two refers to factors influencing attitude of consumption of fruits and vegetables among UUM students.
Likert Scale was used by most previous researches because this scale has a highreliability value. Therefore, the scale used were; 1 as strongly disagrees, 2 as disagree, 3 as uncertain, 4 as agree and 5 as strongly agree.

\subsection{Pilot Study}

A pilot study is essential in a research project before the actual analysis to test the level of reliability and clarity of a question in the research instrument [37]. Besides, pilot study detect the weaknesses in the questionnaire from the respondents' feedback. After analysing the factors on the problem to be studied, researcher distributed a total of 30 questionnaires to the respondents, namely students around UUM. The researcher conducted a pilot study in February 2016 for three days.

Table 1: Pilot Study: Instrument Reliability

\begin{tabular}{lccc}
\hline Instrument & $\begin{array}{c}\text { Cronbach's } \\
\text { Alpha }\end{array}$ & $\begin{array}{c}\text { Cronbach's Alpha } \\
\text { Based on } \\
\text { Standardized Items }\end{array}$ & N of Items \\
\hline Attitude & .936 & .944 & 26 \\
Product & .850 & .851 & 8 \\
Price & .382 & .402 & 6 \\
Place & .558 & .528 & 6 \\
Promotion & .643 & .677 & 10 \\
Knowledge & .758 & .750 & 10 \\
\hline
\end{tabular}

\subsection{Data Analysis Methods}

Data analysis obtained from the questionnaires answered by respondents were examined with Statistical Package for Social Science (SPSS) version 22.0 application. Questionnaires that have been answered was coded into this application as a record before analysing using descriptive and inferential analysis. Descriptive analysis is an analysis that covers the entire study that has been conducted while result referring to several aspects that the researcher wants to observe depending on the researcher.

\subsection{Descriptive Analysis}

Descriptive analysis is an initial picture of a study conducted. It also uses descriptive statistics that involve frequency, percentage, standard deviation, average and ranking. Frequency and percentage are used in evaluating demographic information while for assessment the level of agreement of respondents by using standard and average deviation.

\subsection{Pearson Correlation}

Correlation are usually used in a study to test the relationship between the two variables, namely dependent and independent. Correlation is also a 
quantity or magnitude that represents the relationship strength of the two variables. This study uses Pearson correlation test to test and see if the independent variable which is marketing mix; products, prices, place and promotion, and knowledge significant with dependent variable that is attitude of fruits and vegetables consumption among UUM students.

\subsection{Multiple Regression Analysis}

Multiple regression analysis was to identify and test influence of independent variables i.e. marketing mix; products, prices, place, and promotion, including knowledge of the dependent variables which is attitude of fruit and vegetable consumption among UUM students. Multiple regression analysis was done to recognize the factors contributing to fruit and vegetable consumption among UUM students.

\section{Findings}

\subsection{Overview on Data Collected}

Researchers have distributed a total of 450 sets of questionnaires to undergraduate students at University Utara Malaysia (UUM), and only 400 sets of questionnaires were returned. Following, if the response rate received is $30 \%$, then it is acceptable [36].

\subsection{Correlation Analysis}

Pearson correlation test is a statistical procedure to study the relationship between two variables. Correlation coefficient indicates the extent to which changes in the value of one variable are closely related to changes in other values. The sign in front correlation coefficient $(+$ or - ) indicates the direction of correlation. Most common errors in correlation calculations are related to calculation conditions, interpretation of correlation coefficients and their importance, the height of correlation coefficients, assumptions of cause and effect relationships, correlation strength, and comparison between two correlation coefficients. Table 2 below indicates Pearson correlation coefficients results of the variables used in this study by the researchers.
Table 2: Pearson Correlation Values for Study

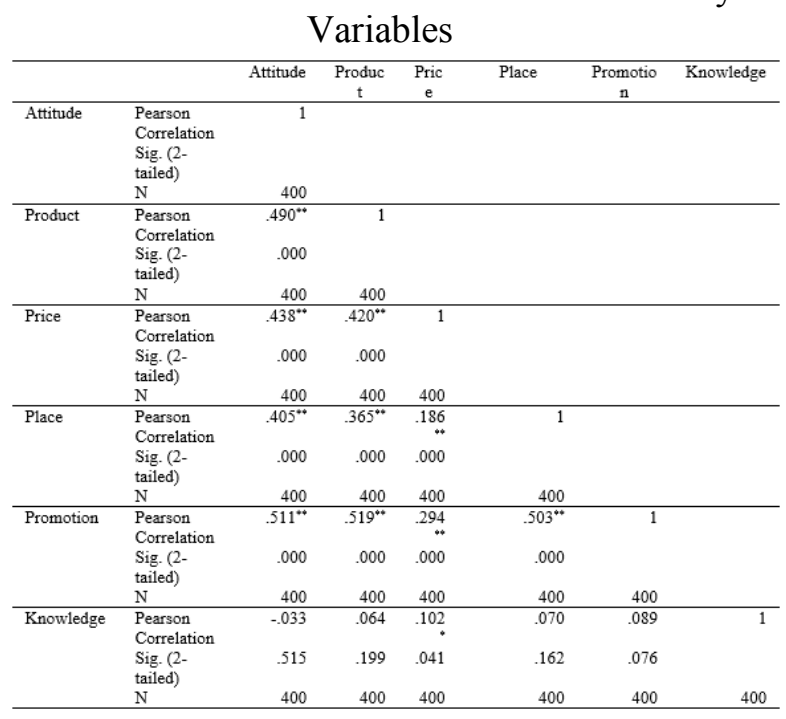

Based on Table 2 above, all the variables tested on frequency are positively related i.e. their value is 0.490 for product and 0.438 for a price, 0.405 for place, and 0.511 for promotion. Meanwhile, for knowledge is -0.33 which indicates a negative value. Some variables have a positive and negative relationship with attitudes which means when high scores on attitude values are related to low scores whether a product, price, place, promotion, and knowledge. Similarly the opposite, if those factors have a high score, is related to a low score of attitude. All variables are in positive value except the knowledge and it is still within the range of correlation rules which is between 1.0 to +1.0 .

In addition, the variables tested are all $\mathrm{p}$ ( $\mathrm{p}$ value) values of $0.000,0.000,0.000,0.000$, and 0.515 , respectively. This indicates that these four variables are significant i.e. $p$ values do not exceed $0.05(\mathrm{p}<0.05)$. However, there is one variable that exceeds the $\mathrm{p}$-value, which is 0.515. Based on the value of $p$ and the correlation can be concluded as follows:

1. It has a significant positive relationship between product and food consumption.

2. It has a significant positive relationship between price and food consumption.

3. It has a significant positive relationship between place and food consumption.

4. It has a significant positive relationship between promotion and food consumption. 
5. It has an insignificant negative relationship between knowledge and food consumption.

\subsection{Multiple Linear Regression Analysis}

Regression analysis involves identifying the relationship between dependent variable and independent variable. Hypothesis relationship model and the parameter value estimation are used to form an estimated regression equation.

Table 3 indicates regression analysis results. These results are used to interpret the strong points of the proposed relationship. After filtration with factor analysis, five hypotheses were stated and all variables were continued for analysis. Next, regression analysis results of this study will be discussed.

Table 3: Multiple Linear Regression Analysis for Variables

\begin{tabular}{ccccc}
\hline Model & $\mathbf{R}$ & R Square & $\begin{array}{c}\text { Adjusted R } \\
\text { Square }\end{array}$ & $\begin{array}{c}\text { Std. Error of } \\
\text { the Estimate }\end{array}$ \\
\hline $\mathbf{l}$ & $.642^{\mathbf{2}}$ & .412 & .404 & .35551 \\
\hline
\end{tabular}

Table 3 shows R-value of the correlation coefficient between attitude and product, price, place, promotion, and knowledge is 0.642, which is $64.2 \%$ independent variables (product, price, place, promotion, and knowledge) have influenced fruit consumption fruits and vegetables among students. $\mathrm{R}$ square 0.412 equivalent to $41.2 \%$ showing that the changes in attitudes in the consumption of fruits and vegetables are influenced by the five independent variables of $64.2 \%$.

Table 4: Coefficient

\begin{tabular}{|c|c|c|c|c|c|c|}
\hline \multirow[t]{2}{*}{ Mode } & & \multicolumn{2}{|c|}{$\begin{array}{c}\text { Unstandardized } \\
\text { Coefficients }\end{array}$} & \multirow{2}{*}{$\begin{array}{c}\begin{array}{c}\text { Standardized } \\
\text { Coefficients }\end{array} \\
\text { Beta } \\
\end{array}$} & \multirow[t]{2}{*}{$t$} & \multirow[t]{2}{*}{ Sig. } \\
\hline & & B & Std. Error & & & \\
\hline \multirow[t]{6}{*}{1} & (Constant) & 1.461 & .268 & & 5.455 & .000 \\
\hline & product & .176 & .044 & 191 & 3.960 & .000 \\
\hline & price & .238 & .039 & .261 & 6.079 & .000 \\
\hline & place & .148 & .041 & .162 & 3.582 & .0000 \\
\hline & promotion & .244 & .046 & .263 & 5.325 & .000 \\
\hline & knowledge & -.226 & .083 & -.106 & -2.730 & .007 \\
\hline
\end{tabular}

Table 4 shows the conclusions to look at the aspects influences attitude of fruits and vegetables consumption among students. The $t$ values and significance for the five independent variables were product $(3,960,0.000)$, price $(6.079,0.000)$, place $(3.582,0.000)$, promotion $(5.325,0.000)$, and knowledge $(-2.730,0.007)$. This indicates that product, price, place, and promotion is significant with attitude i.e. $\mathrm{p}=$ $0.000<0.05$.

\section{Conclusion}

Research was done to examine whether marketing mix factors, product, price, promotion as well as distribution and knowledge affect the attitude of fruit and vegetable consumption among Universiti Utara Malaysia students. To achieve research objective, first data was collected through survey questions distributions to students randomly to answer the questionnaire. Data were obtained from the population involving UUM undergraduate students using a sample size of 450 sets of questions. Correlation analysis results have proven that the independent variables in this study, which are product marketing, price, promotion and distribution have a positive and significant relationship while knowledge is insignificant with the consumption pattern of fruits and vegetables among UUM students.

Lacking in proper knowledge on healthy food may result in a silent chronic exposure to human health and are fatal to them (38). Health promotion within the university students may reduce the prevalence health risk (39).

The knowledge of promoting a healthy lifestyle, specifically on increasing fruit and vegetables and consumption among university students can be planned. From health perspective, there might be challenges in developing effective strategies to motivate students to increase their fruits and vegetable intake. It seems that this cannot be achieved only by imparting knowledge of healthy eating. Students may have difficulties to correctly estimate the amounts of fruits and vegetables that make up one serving. Promoting healthy eating among students, considering both the amount of servings and the serving size can be developed. Consequently, increasing freshness and quality standard of fruits and vegetables in the market will increase the fruits and vegetables consumption among Malaysian university students.

\section{Acknowledgement}

Yaty Sulaiman is an Associate Professor of Marketing, School of Business Management, College of Business, Universiti Utara Malaysia 06010 Sintok, Kedah, Malaysia. The authors would like to thank The Ministry of Higher Education (MOHE) for granting this research under the Fundamental Research Grant Scheme 
(FRGS) and Research Innovation Management Centre (RIMC) Universiti Utara Malaysia. This article is under FRGS grant research.

\section{References}

[1] Steven, T. Y., Andrew, K. G. T., \& Rodolfo, M. N. J. (2011). Determinants of fruit and vegetable consumption in Malaysia: An ordinal system approach. The Australian Journal of Agricultural and Resource Economics, 55, 239-256.

[2] Devine, C.M., Connors, M., Bisogni, C.A. and Sobal J. 1998. Life-course influences on fruit and vegetable trajectiroes: qualitative analysis of food choices. Journal of Nutrition and Education, 30(6), 361-370.

[3] Sulaiman, Y., Bakar, N. N. A.A., Ismail, M. Y. S., Mat, N. K. N., Musa, R. (2017). The Function of Marketing Mix and Consumer Preferences on Healthy Food Consumption among UUM Students. International Journal of Economic Research. 14 (19), 0972-9380

[4] Sulaiman, Y., Masri, M., Yusr. M. M., Ismail, M. Y. S., Mustafa, S. A., Salim, N. (2017). The Relationship between Marketing Mix and Consumer Preference in Supplement Product Usage. International Journal of Economic Research. 14 (19), 0972-9380

[5] Dietary Guidelines for Americans, 2010. Retrieved from: http://www.dietaryguidelines.gov. Produce for Better Health Foundation, 2011. Retrieved from: http://www.pbhfoundation.org/.

[6] Sulaiman, Y., Jauhari, N. (2021). The Factors Influencing Mobile Banking Usage among University Staff. WSEAS Transactions on Business and Economics. (18), 2224-2899. DOI: 10.37394/23207.2021.18.19

[7] Ibrahim, F. M. (2011): Fruity response efficacy and fruit consumption among a group of civil servants of Oyo State, Nigeria. American Journal of Food and Nutrition, 1(1), 44-48.

[8] Banwat, M.E, Lar, L.A., Daboer J., Audu, S. and Lassa S. (2012). Knowledge and Intake of Fruit and Vegetables Consumption among Adults in an Urban
Community in North Central Nigeria. The Nigerian Health Journal, 12(1), 12-15.

[9] Othman, K., Ab Karim, M., Karim, R., Adzham, N., Abdul Halim, N., \& Osman, S. (2012). Factors Influencing Fruits and Vegetables Consumption Behaviour among Adults in Malaysia. Journal of Agribusiness Marketing, 5, 29- 46.

[10] Mat, N. K. N., Sulaiman, Y., Ghani, N. H. A., Mohamad, M. (2018). Halal Consumption Pattern Determinants: Sequential Mediating effects of Muslim Lifestyle, Trust and Risk Perception. The Journal of Social Sciences Research. 6, pp: 444-453. DOI: https://doi.org/10.32861/jssr.spi6.444.45 3

[11] Ajzen, I. (1991). The theory of planned behavior. Organizational Behavior and Human Decision Processes, 50(2), 179211.

[12] Perera, T., \& T., Madhujith. (2012). The Pattern of Consumption of Fruits and Vegetables by Undergraduate Students: A Case Study. Tropical Agricultural Research, 23 (3), $261-271$.

[13] Lucia A. Leone, Diane Beth, Scott B. Ickes, Kathleen MacGuire, Erica Nelson, Robert Andrew Smith, Deborah F. Tate \& Alice S. Ammerman (2012) Attitudes Toward Fruit and Vegetable Consumption and Farmers' Market Usage Among Low-Income North Carolinians, Journal of Hunger \& Environmental Nutrition, 7(1), 64-76.

[14] Glanz. K, \& Hoelscher D. (2004). Increasing fruit and vegetable intake by changing environments, policy, and pricing: Restaurant-based research, strategies, and recommendation. Preventive Medicine, 39, 88-93.

[15] Bandura. A. (1991). Health Promotion by Social Cognitive Means. Health Education \& Behavior, Vol. 31 (2): 143164

[16] Vermeir, Iris. \& Verbeke, Wim. (2004). Sustainable Food Consumption: Exploring the Consumer AttitudeBehavior gap. Working paper.

[17] Steven T. Yen, Andrew K. G. Tan, and Mustapha I. Feisul. (2012). Consumption of Fruits and Vegetables in Malaysia: Profiling the Daily and Nondaily Consumers. Asia-Pacific Journal of Public Health. 
[18] Tolusic, Z., Zmaic, K., \& Deže, J. (2002). Marketing-Mix in the Function of the Organic Food of Eastern Croatia. agroekonomiku, 53 (7-8), 782-794

[19] Zhen, J., \& Mansori, S. (2012). Young Female Motivations for Purchase of Organic Food in Malaysia. International Journal of Contemporary Business Studies, 3(5).

[20] Kotler, P., Armstrong, G., Wong, V., \& Saunders, J. (2008). Principles of Marketing. London: Prentice Hall.

[21] Sulaiman, Y., Jamil, N. A. M., Othman, A. R., Musa, R. (2020). The Influence of Green marketing, Syariah Compliance, Customer's Environmental Awareness and Customer's Satisfaction towards Muslim Consumer Purchasing Behaviour in Kedah. WSEAS Transactions on Business and Economics. (17), 22242899. DOI: $10.37394 / 23207.2020 .17 .21$

[22] Source: Boundless. "Product, Placement, Promotion, and Price." Boundless Marketing. Boundless, 21 Jul. 2015.

[23] Millock, K., Hansen, L.G., Wier, M. and Anderson, L.M. (2007). Willingness to pay for organic foods: A comparison between survey data and panel data from Denmark. CIRED, France.

[24] Sulaiman, Y., Kan, W. P. E., Salimon, M. G., (2020). Purchase Intention towards Organic Food among Undergraduate Students. WSEAS Transactions on Environment and Development. (16), 2224-3496.

DOI:

[32] Hilliam, M. (1996). Functional foods: The Western consumer viewpoint. Nutrition Reviews, 54(11), S189.

[33] Brug J, Oenema A, Ferreira I. Theory, evidence and Intervention Mapping to improve behavioral nutrition and physical activity interventions. Int $J$ Behav Nutr Phys Act. 2005; 2: 2. doi: 10.1186/14795868-2-2

[34] Tambrin, M. (2014). Hubungan Bauran Pemasaran dan Keputusan Pembelian Konsumen Tiket Bis Krimat Djati Melalui Agen Travel di Bangkalan. Jurnal Studi Manajemen, 26-34.

[35] Krejcie, R. V, \& Morgan, D. W. (1970). Determining sample size for research activities. Educational and Psychological Measurement, 30, 607-610.
$10.37394 / 232015.2020 .16 .76$

[25] Anderson, W. P., L. Chatterjee and T. Lakshmanan, 2003. E commerce, Transportation and Economic Geography. Growth and Change, 34(4), 415-432.

[26] Nezakati, H. A. (2011). Adopting Elements of Market Value Coverage in Adoption and Diffusion of InnovationsFast Food Industries. Australian Journal of Basic and Applied Sciences. 5 (9), 1271-1276

[27] Azqueta, D. (2002). Introduction to environmental economics. Madrid, España: McGraw Hill.

[28] Martinsons, M. G., So, S. K. K., Tin, C., \& Wong, D. (1997). Hong Kong and China: Emerging markets for environmental products and technologies. Long Range Planning, 30(2), 277-290.

[29] Handfield, R. B., Melnyk, S. A., Calantone, R. J., \& Curkovic, S. (2001). Integrating environmental concerns into the design process: The gap between theory and practice. IEEE Transactions on Engineering Management, 48(2), 189209.

[30] Hassan, S., \& Mustapha, Y. (2010). Malaysian Consumer Knowledge And Preferred Information Sources In Selecting Functional Foods. Malaysian Consumer Knowledge and, 3, 20-39.

[31] Bhaskaran, S., \& Hardley, F. (2002). Buyer beliefs, attitudes and behaviour: Foods with therapeutic claims. Journal of Consumer Marketing, 19(7), 591.

[36] Sekaran, U., \& Bougie, R. (2010). Research methods for business a skill building approach $\left(15^{\text {th }}\right.$ ed). United Kingdom: Wiley

[37] Neuman, W. L. (2006): Social Research Methods: Qualitative and Quantitative Approaches. Boston, Pearson Education. Approach $\left(15^{\text {th }}\right.$ ed $)$. United Kindom: Wiley.

[38] Manolis N. Kokkinakis, Manolis N. Tzatzarakis, Ioannis Tsakiris, Alexander I. Vardavas, Constantine I. Vardavas, Polychronis Stivaktakis, Aikaterini Kokkinaki, Pesticide residue monitoring in the European Union Agricultural Sector via modern analytical techniques. A review on Organophosphates, International Journal of Biology and 
Biomedical Engineering, pp. 169-179, Volume 14, 2020.

[39] Mubashir Zafar, Eltigani Osman Musa Omer, Osama Ahmed Labib Ibrahim, Arafat Mohammed Goja, Evidence based Intervention to Prevent Anemia Among Women of Reproductive Age Group in Developing Countries; Review, International Journal of Biology and Biomedical Engineering, pp. 58-62, Volume 13, 2019.
Creative Commons Attribution License 4.0 (Attribution 4.0 International, CC BY 4.0)

This article is published under the terms of the Creative Commons Attribution License 4.0

https://creativecommons.org/licenses/by/4.0/deed.en US 